ISSN: 2224-0616

Int. J. Agril. Res. Innov. \& Tech. 7 (1): 58-63, J une, 2017

Available online at http:// www.ijarit.webs.com

\title{
IMPACT OF GENETICALLY IMPROVED FISH SPECIES AND TECHNOLOGY ON SELECTED HATCHERY AND FISH PRODUCTION IN BANGLADESH
}

\author{
M.S. Islam1, A.H.M. Kohinoor', M.M. Rahman ${ }^{3 *}$, M.M. Haque ${ }^{4}$ \\ Received 30 April 2017, Revised 4 June 2017, Accepted 26 June 2017, Published online 30 June 2017
}

\begin{abstract}
The study was carried out in IAPP commanding areas from July to September 2015. A total of 8 hatchery and 240 farmers were selected for this study from Rangpur and Barisal region. About 153\% Tilapia production increased which was from 34 to 86 lakh, which was 148\% in Rangpur district. Thai koi production was increased about 320\% in Rangpur and it was $152 \%$ in Barisal. It was observed that, per hatchery Tilapia profit was Tk. 17.35 lakh and Tk. 17.18 lakh in Rangpur and Barisal, respectively. While, total profit was 3.9 times more for Thai koi in Rangpur and it was about 1.7 times more in Barisal after IAPP-BFRI project implementation. Impact of improved germplasm on grow out system was estimated. Finding shows that before IAPP-BFRI project the average harvesting weight of tilapia fish was $122 \mathrm{~g}$ but after using IAPP-BFRI germplasm, it increased to $194 \mathrm{~g}$ in Rangpur district. In case of Thai Koi, the harvesting weight gain was $26 \%$ in Rangpur district and it was statistically significant at $1 \%$ level. Survey results also show that per acre profit was only Tk.86671 for Tilapia farming before IAPP whereas it was increased to Tk. 234853 after IAPP-BFRI intervention. At the same time, profit from Thai Koi was increased about 189\% after IAPPBFRI activities. Similarly, profit was increased about $86 \%$ in case of Pangus farming and this positive impact was statistically significant at $1 \%$ level. Therefore, it may conclude that, farmers can significantly increase Tilapia, Thai Koi and Pangus production as well as can maximize profit using IAPP technology.
\end{abstract}

Keywords: Genetically Improved, Hatchery, Fish Production, Bangladesh

${ }^{1}$ Senior Scientific Officer, Bangladesh Fisheries Research Institute, Mymensingh-2201, Bangladesh.

${ }^{2}$ Principal Scientific Officer, Freshwater Station, Bangladesh Fisheries Research Institute, Mymensingh-2201, Bangladesh.

${ }^{3}$ Scientific Officer, Freshwater Station, Bangladesh Fisheries Research Institute, Mymensingh-2201, Bangladesh.

${ }^{4}$ Associate Professor, Graduate Training Institute, Bangladesh Agricultural University, Mymensingh-2202, Bangladesh.

*Corresponding author's email: riad242@gmail.com (M.M. Rahman)

\section{Introduction}

Bangladesh is endowed with unique aquatic resources for fish and fisheries development. The inland water resources of this country are considered to be one of the richest in the world both in terms of area and its potential for fisheries development. Fisheries sector is contributing in food security through proving safe and quality animal protein; almost $60 \%$ animal protein comes from fish. It contributes 3.69\% to our national GDP and around one fourth (23.12\%) to the agricultural GDP (FRSS, 2016). It provides full time employment to about 1.20 million people and generates part time employment for 11 million people. Around $10 \%$ of total export earnings come from fisheries. It was argued that rural aquaculture plays a significant role in Bangladesh in view of its contribution towards national food and nutritional security, rural job opportunities and income (Mazid and Sinha, 2000). Rural aquaculture thus needs much more attention now than ever before. Although Bangladesh is rich in vast water resources but per hectare yield from ponds only 3.0 tones per year. This can further be augmented. The yield of inland fisheries is therefore could be increased substantially through adopting appropriate aquaculture technologies and judicious as well as efficient uses of existing resources. However, sustainable aquaculture technologies as well as quality fish fry are required in this country for increasing production of fisheries.

Integrated Agricultural Productivity Project (IAPP) is donor funded project. This project is implemented by Ministry of Agriculture and Ministry of Fisheries and Livestock, Bangladesh. Under this project eight agencies (DAE, DLS, DOF, BADC, BARI, BRRI, BFRI and SCA) are working together to promote productivity of crops, livestock and fish. During 2011-16, with the financial assistance GAFSP, BFRI has been working for developing improved generation of GIF tilapia, Thai Koi and Pangus. During the timeframe, BFRI have successfully developed 04 
generation of GIF tilapia, 03 generation of Thai Koi and 02 generation of Pangus through selective breeding. These improved generations were distributed to eight selected private hatcheries of Rangpur and Barisal region for mass seed production. These selected hatcheries are being produced millions of quality fry from BFRI supplied improved generation and sold out among IAPP fisheries group member. The IAPP group members were growing table sized fish for economic welfare. The present study was undertaken to analyze the potential impact of quality fry production in hatcheries and culturing the improved generations on fish production and profitability of fish farming.

\section{Materials and Methods}

The investigation was carried out in IAPP areas from July to September 2015. Integrated Agricultural Productivity Project (IAPP) worked in 54 upazillas in Rangpur, Kurigram, Lalmonirhat, Nilphamari, Barisal, Jalokathi, Patuakhali and Borguna. The survey schedule was prepared to record the required information on various aspects of fish farming activities. A total of 8 hatchery and 240 farmers were selected from Rangpur and Barisal region for this study. After the schedule was finalized, the selected farmers were interviewed individually by personal interviews when they had little work on the farms. Before the actual interview was made, the aim and purpose of the study were explained to each hatchery operator and farmers.

\section{Analytical technique}

Data, thus collected, were analyzed in accordance with the objectives of the study. In this study, the tabular technique of analysis was used. The tabular technique of analysis included classification of the data in the form of tables. It is generally used to find out the crude association of difference between two sets of variables. This technique is based on arithmetic mean, percentage, ratio, etc.

\section{Results}

Table 1 shows the average fry production and its profitability status in Rangpur and Barisal district. Fry of Tilapia production has reached to about 87 lakh per hatchery per year after IAPP implementation, which was only 35 lakh before the project implying that Tilapia fry production has increased about 148\% in Rangpur district. Same success was observed in Barisal. About $153 \%$ Tilapia production has increased which is from 34 lakh to 86 lakh. On the other hand, a significant change has occurred in case of Thai koi in Rangpur district. Thai koi production has increased about 320\% in Rangpur and it was $152 \%$ in Barisal. Cost of production has increased with fry production but profitability has increased significantly for both places and species. It is found that per hatchery Tilapia profit was Tk. 17.35 lakh and Tk. 17.18 lakh in Rangpur and Barisal, respectively. On the other hand, total profit was 3.9 times more for Thai koi in Rangpur and it was about 1.7 times more in Barisal after IAPP implementation. Therefore, it can be concluded that, a significant success has achieved in case of fry production and profit in hatchery.

Table 1. Average fry production status.

\begin{tabular}{|c|c|c|c|c|c|c|c|c|}
\hline \multirow[b]{2}{*}{ Particulars } & \multicolumn{4}{|c|}{ Rangpur } & \multicolumn{4}{|c|}{ Barisal } \\
\hline & $\begin{array}{c}\text { Fish } \\
\text { Species }\end{array}$ & $\begin{array}{l}\text { Before } \\
\text { IAPP }\end{array}$ & $\begin{array}{l}\text { After } \\
\text { IAPP }\end{array}$ & $\begin{array}{c}\text { Increase } \\
(\%)\end{array}$ & $\begin{array}{c}\text { Fish } \\
\text { Species } \\
\end{array}$ & $\begin{array}{l}\text { Before } \\
\text { IAPP }\end{array}$ & $\begin{array}{l}\text { After } \\
\text { IAPP }\end{array}$ & $\begin{array}{c}\text { Increase } \\
(\%)\end{array}$ \\
\hline \multirow{2}{*}{$\begin{array}{c}\text { Fry } \\
\text { produced/year/ } \\
\text { Farm } \\
\text { (Lakh) }\end{array}$} & Tilapia & 35.00 & 86.76 & 148 & \multirow{2}{*}{$\begin{array}{l}\text { Tilapia } \\
\text { Pangus }\end{array}$} & 34.00 & 85.93 & 153 \\
\hline & Thai Koi & 5.00 & 21.00 & 320 & & 26.00 & 65.60 & 152 \\
\hline \multirow{2}{*}{$\begin{array}{l}\text { Total cost of Fry } \\
\text { production } \\
\text { (Lakh) }\end{array}$} & $\begin{array}{c}\text { Tilapia } \\
\text { (0.30 } \\
\text { Tk./fry) }\end{array}$ & 10.50 & 26.03 & 148 & $\begin{array}{l}\text { Tilapia } \\
(0.30 \\
\text { Tk./fry) }\end{array}$ & 10.20 & 25.78 & 153 \\
\hline & $\begin{array}{c}\text { Thai Koi } \\
(0.32 \\
\text { Tk./fry) }\end{array}$ & 1.60 & 6.72 & 320 & $\begin{array}{l}\text { Pangus } \\
(0.40 \\
\text { Tk./fry) }\end{array}$ & 10.40 & 26.24 & 146 \\
\hline \multirow{2}{*}{$\begin{array}{l}\text { Total return of } \\
\text { Fry production } \\
\text { (Lakh) }\end{array}$} & $\begin{array}{c}\text { Tilapia } \\
\text { (0.50 } \\
\text { Tk./fry) }\end{array}$ & 17.50 & 43.38 & 148 & $\begin{array}{l}\text { Tilapia } \\
(0.50 \\
\text { Tk./ fry) }\end{array}$ & 17.00 & 42.96 & 152.71 \\
\hline & $\begin{array}{c}\text { Thai Koi } \\
(0.60 \\
\text { Tk./fry) }\end{array}$ & 3.0 & 12.60 & 320 & $\begin{array}{l}\text { Pangus } \\
(0.70 \\
\text { Tk./fry })\end{array}$ & 25.20 & 45.92 & 82.22 \\
\hline \multirow{2}{*}{$\begin{array}{l}\text { Total profit } \\
\text { (Lakh) }\end{array}$} & Tilapia & 7.00 & 17.35 & 148 & Tilapia & 6.8 & 17.18 & 152.65 \\
\hline & Thai Koi & 0.85 & 3.72 & 337 & Pangus & 14.80 & 19.68 & 32.97 \\
\hline \multirow{2}{*}{$\begin{array}{l}\text { No of farmer } \\
\text { collected fry }\end{array}$} & Tilapia & 205 & 426 & 107 & Tilapia & 178 & 360 & 102 \\
\hline & Thai Koi & 54 & 262 & 385 & Pangus & 96 & 257 & 168 \\
\hline
\end{tabular}


It was found that after IAPP implementation, fertilization rate for Tilapia fingerling has increased about 13 and 16 percent in Rangpur and Barisal district (Table 2). It was 11 percent and 5 percent for Thai Koi in Rangpur and Barisal respectively. On the contrary, hatching rate has increased for Tilapia from 84 percent to 95

Table 2. Average survival status during incubation.

\begin{tabular}{ccccccccc}
\hline \multirow{2}{*}{ Particulars } & \multicolumn{4}{c}{ Rangpur } \\
\cline { 2 - 9 } & $\begin{array}{c}\text { Fish } \\
\text { Species }\end{array}$ & $\begin{array}{c}\text { Before } \\
\text { IAPP }\end{array}$ & $\begin{array}{c}\text { After } \\
\text { IAPP }\end{array}$ & $\begin{array}{c}\text { Increase } \\
(\%)\end{array}$ & $\begin{array}{c}\text { Fish } \\
\text { Species }\end{array}$ & $\begin{array}{c}\text { Before } \\
\text { IAPP }\end{array}$ & $\begin{array}{c}\text { After } \\
\text { IAPP }\end{array}$ & $\begin{array}{c}\text { Increase } \\
(\%)\end{array}$ \\
\hline Fertilization & Tilapia & 80 & 90 & 13 & Tilapia & 80 & 93 & 16 \\
(\%) & Thai Koi & 75 & 83 & 11 & Pangus & 78 & 82 & 5 \\
Hatching & Tilapia & 84 & 95 & 13 & Tilapia & 82 & 90 & 9 \\
(\%) & Thai Koi & 82 & 85 & 4 & Pangus & 79 & 85 & 8 \\
Survival & Tilapia & 80 & 86 & 8 & Tilapia & 81 & 88 & 9 \\
(\%) & Thai Koi & 76 & 83 & 9 & Pangus & 80 & 85 & 6 \\
\hline
\end{tabular}

Table 3 shows the average survival rate of fry and weight was gained from $140 \mathrm{mg} /$ fry to 200 weight of fry after treatment. Survival rate of fry $\mathrm{mg} /$ fry during hormone treatment in Rangpur during hormone treatment has increased about and it has increased from $120 \mathrm{mg} /$ fry to 270 10 and 9 percent in Rangpur and Barisal for $\mathrm{mg} /$ fry in Barisal. Tilapia, respectively. On an average, average

Table 3. Average survival status of fry during hormone treatment.

\begin{tabular}{ccccccccc}
\hline \multirow{2}{*}{ Particulars } & \multicolumn{4}{c}{ Rangpur } & \multicolumn{4}{c}{ Barisal } \\
\cline { 2 - 8 } & $\begin{array}{c}\text { Fish } \\
\text { Species }\end{array}$ & $\begin{array}{c}\text { Before } \\
\text { IAPP }\end{array}$ & $\begin{array}{c}\text { After } \\
\text { IAPP }\end{array}$ & $\begin{array}{c}\text { Increas } \\
\mathrm{e}(\%)\end{array}$ & $\begin{array}{c}\text { Fish } \\
\text { Species }\end{array}$ & $\begin{array}{c}\text { Before } \\
\text { IAPP }\end{array}$ & $\begin{array}{c}\text { After } \\
\text { IAPP }\end{array}$ & $\begin{array}{c}\text { Increase } \\
(\%)\end{array}$ \\
\hline $\begin{array}{c}\text { Survival rate } \\
\text { of fry }\end{array}$ & & 83 & 91 & 10 & & 83 & 91 & 9 \\
$\begin{array}{c}\text { Average } \\
\text { weight of fry } \\
\text { after } \\
\text { treatment }\end{array}$ & Tilapia & 140 & 200 & 43 & Tilapia & 120 & 270 & 125 \\
mg/fry & mg/fry & $43 /$ fry & mg/fry & \\
\hline
\end{tabular}

Table 4 shows the survival rate of fry and average weight gain of fry after treatment during primary nursing stage. It was found that after IAPP survival rate of Tilapia increased about 16 percent and 8 percent in Rangpur and Barisal, respectively during nursing period. On the other hand, survival rate was very low (55\%) before the IAPP project for Thai Koi in Rangpur but it reached to 67 percent after commencement of the percent in Rangpur and from 82 percent to 90 percent in Barisal. Survival rate shows the improvement which was increased was 8 to 9 percent for Tilapia and for Thai Koi it was increased about 9 percent after IAPP implementation.

Table 4. Average survival status during primary nursing stage.

\begin{tabular}{|c|c|c|c|c|c|c|c|c|}
\hline \multirow[b]{2}{*}{ Particulars } & \multicolumn{4}{|c|}{ Rangpur } & \multicolumn{4}{|c|}{ Barisal } \\
\hline & $\begin{array}{c}\text { Fish } \\
\text { Species }\end{array}$ & $\begin{array}{l}\text { Before } \\
\text { IAPP }\end{array}$ & $\begin{array}{l}\text { After } \\
\text { IAPP }\end{array}$ & $\begin{array}{c}\text { Increase } \\
(\%)\end{array}$ & $\begin{array}{c}\text { Fish } \\
\text { Species }\end{array}$ & $\begin{array}{l}\text { Before } \\
\text { IAPP }\end{array}$ & After IAPP & $\begin{array}{c}\text { Increase } \\
(\%)\end{array}$ \\
\hline Survival & Tilapia & 70 & 81 & 16 & Tilapia & 85 & 92 & 8 \\
\hline rate of fry & Thai Koi & 55 & 67 & 22 & Pangus & 82 & 88 & 7 \\
\hline $\begin{array}{l}\text { Average } \\
\text { weight of }\end{array}$ & Tilapia & 3.0 & 8.4 & 180 & $\begin{array}{l}\text { Tilapia } \\
\text { Pangus }\end{array}$ & 5.0 & 12.0 & 140 \\
\hline $\begin{array}{c}\text { treatment } \\
\text { tg }\end{array}$ & Thai Koi & 4.0 & 7.5 & 88 & & 25.0 & 47.0 & 88 \\
\hline
\end{tabular}


Table 5 shows how many people were trained through this project and how much area has increased due to project implementation. It was found that after project implementation, average hatchery staff increased about 60 percent and 80 percent in Rangpur and Barisal district, respectively. Through this project, a total of 6 hatchery staffs were trained in Rangpur and it was 8 staff in Barisal. In case of physical structure, after project implementation, hatchery area was increased from 8 acre to 13 acre in Rangpur district but there no change was observed in Barisal. On contrary, breeding pond area has increased about 66 percent and 50 percent in Rangpur and Barisal, respectively. On the other hand, nursery area has increased from 5 acre to 7 acre in Rangpur and it has increased from 4 acre to 7 acre in Barisal.

Table 5. Capacity building (Manpower \& Infrastructure).

\begin{tabular}{lcccccc}
\hline Particulars & \multicolumn{3}{c}{ Rangpur } & \multicolumn{2}{c}{ Barisal } \\
\cline { 2 - 7 } & $\begin{array}{c}\text { Before } \\
\text { IAPP }\end{array}$ & $\begin{array}{c}\text { After } \\
\text { IAPP }\end{array}$ & $\begin{array}{c}\text { Increase } \\
(\%)\end{array}$ & $\begin{array}{c}\text { Before } \\
\text { IAPP }\end{array}$ & $\begin{array}{c}\text { After } \\
\text { IAPP }\end{array}$ & $\begin{array}{c}\text { Increase } \\
(\%)\end{array}$ \\
\hline $\begin{array}{l}\text { Average hatchery Staff (No.) } \\
\text { Average hatchery staff trained } \\
\text { (No.) }\end{array}$ & 10 & 16 & 60 & 10 & 18 & 80 \\
Physical Structure & 2 & 6 & 200 & 3 & 8 & 166 \\
Area of hatchery (Acre) & 8 & 13 & 50 & 30 & 30 & 0 \\
Breeding pond (Acre) & 3 & 5 & 66 & 10 & 15 & 50 \\
Nursery pond (Acre) & 5 & 7 & 40 & 4 & 7 & 75 \\
\hline
\end{tabular}

\section{Grow out Results}

Impact of IAPP was estimated in various steps of production such as harvesting weight gain, production gain, survival rate increased, production cost increased or decreased and profit earn. Table 6 shows the average harvesting weight of Tilapia and Thai Koi in greater Rangpur and Barisal district. Two sample mean comparison test was performed to estimate whether the impact of IAPP technology is significant or not. Finding shows that before IAPP the average weight of tilapia fish was $122(\mathrm{~g})$ per fish at harvesting time but after using IAPP technology, it increased to $194 \mathrm{gm}$ per fish in Rangpur district. It implies that farmers are able to gain about 59\% harvesting weight using IAPP technology in Rangpur district, which was statistically significant at $1 \%$ level. In case of Thai Koi, the harvesting weight gain was $26 \%$ (from 80 $\mathrm{gm}$ to $101 \mathrm{gm}$ ) in Rangpur district and it was statistically significant at $1 \%$ level.

Table 6. Average harvesting weight (g) of Rangpur and Barisal region.

\begin{tabular}{cccccc}
\hline \multirow{2}{*}{ Particulars } & \multicolumn{5}{c}{ Harvesting weight (g) } \\
\cline { 2 - 6 } & Fish Species & Before IAPP & After IAPP & Increase (\%) & t-value \\
\hline \multirow{2}{*}{ Rangpur } & Tilapia & 122 & 194 & 59 & 12.93 \\
& Thai Koi & 80 & 101 & 26 & 18.05 \\
\multirow{2}{*}{ Barisal } & Tilapia & 127 & 170 & 34 & 17.65 \\
& Pangus & 741 & 1035 & 40 & 16.06 \\
\hline
\end{tabular}

Tilapia and Pangus species was used to assess the impact of IAPP technology in Barisal district. Result shows that before IAPP, on an average per tilapia weight was $127 \mathrm{~g}$ at harvesting time but it grew up to $170 \mathrm{gm}$ after IAPP. It implies that about 34\% harvesting was gain from per tilapia after using IAPP technology and this gain was statistically significant at $1 \%$ level. On the other hand, about $40 \%$ harvesting weight was gain (from $741 \mathrm{~g}$ to $1035 \mathrm{~g}$ ) from per fish after using IAPP technology in case of pangus species and this gain was significant at $1 \%$ level.

To assess the impact of IAPP on productivity, per acre fish production was estimated for Tilapia,
Thai Koi and Pangus in Rangpur and Barisal district (Table 7). Result reveals that per acre Tilapia fish productivity increased 1.99 times after using IAPP technology and it has reached to $4799 \mathrm{~kg}$ acre ${ }^{-1}$. On the other hand, a remarkable change has been achieved in Thai Koi. Before IAPP, farmers were able to produce about 2002 $\mathrm{kg}$ Thai Koi in one acre of pond area but after using IAPP technology, farmers produced 3655 $\mathrm{kg}$ Thai Koi within the same area of pond implies that $82 \%$ productivity can be increased through using IAPP technology in case of Thai Koi. This productivity gain was statistically significant at $1 \%$ level for both species of fish. 
Table 7. Average production ( $\mathrm{kg} \mathrm{acre}^{-1}$ ) of Rangpur and Barisal region.

\begin{tabular}{cccccc}
\hline \multirow{2}{*}{ Particulars } & \multicolumn{5}{c}{ Production (Kgacre- ${ }^{-1}$ ) } \\
\cline { 2 - 6 } & Fish Species & Before IAPP & After IAPP & Increase (\%) & t-value \\
\hline \multirow{2}{*}{ Rangpur } & Tilapia & 2413 & 4799 & 99 & 15.29 \\
& Thai Koi & 2002 & 3655 & 82 & 28.56 \\
\multirow{2}{*}{ Barisal } & Tilapia & 2489 & 3195 & 28 & 14.20 \\
& Pangus & 7810 & 11176 & 43 & 17.57 \\
\hline
\end{tabular}

On the other hand, farmers were able to increase production about $28 \%$ in case of Tilapia after using IAPP technology in Barisal district. The productivity increased from $2489 \mathrm{~kg}$ acre $^{-1}$ to $3195 \mathrm{~kg}$ acre ${ }^{1}$, which was significant at $1 \%$ level. A notable achievement was found in case of Pangus production in Barisal. Result reveals that on an average Pangus productivity has increased about $43 \%$ after using IAPP technology. Before IAPP technology, farmers produced only $7810 \mathrm{~kg}$
Pangus in one acre of pond area but it has increased to $11176 \mathrm{~kg}$ after IAPP project.

Before, IAPP project, the survival rate was $82 \%$ and $77 \%$ for Tilapia and Thai Koi respectively in Rangpur district but after IAPP project, it has increased to $91 \%$ and $89 \%$, respectively (Table 8 ). On an average, survival rate was increased $10 \%$ and $15 \%$ for Tilapia and Thai Koi, which was statistically significant at $1 \%$ level.

Table 8. Average survival rate of Rangpur and Barisal region.

\begin{tabular}{cccccc}
\hline \multirow{2}{*}{ Particulars } & \multicolumn{5}{c}{ Survival rate } \\
\cline { 2 - 6 } & Fish Species & Before & After IAPP & Increase (\%) & t-value \\
\hline \multirow{2}{*}{ Rangpur } & Tilapia & 82 & 91 & 10 & 19.55 \\
& Thai Koi & 77 & 89 & 15 & 20.56 \\
\multirow{2}{*}{ Barisal } & Tilapia & 72 & 90 & 25 & 48.18 \\
& Pangus & 74 & 89 & 20 & 27.03 \\
\hline
\end{tabular}

On average, 25\% survival rate has increased for Tilapia which was $72 \%$ before IAPP but after IAPP is increased to $90 \%$. On the other hand, Pangus survival rate has increased about $20 \%$ (from $74 \%$ to $89 \%$ ) and it was statistically significant at $1 \%$ level. This increase of survival rate was lead to increase the productivity and profitability of the farm.
In this section, we only show the comparative scenario of production cost for before and after IAPP. Finding shows that, production cost was Tk. 56 for producing per $\mathrm{kg}$ of Tilapia fish before IAPP but after project, it increased to Tk. 66 implies that production cost has increased about $17 \%$ for Tilapia in Rangpur region. Alternatively, cost for per kg Thai Koi production has increased about $15 \%$ (from Tk. 70 to $\mathrm{Tk}$. 81) and these increases was statistically significant (Table 9).

Table 9. Average Production cost (Tk./kg) of Rangpur and Barisal region.

\begin{tabular}{cccccc}
\hline \multirow{2}{*}{ Particulars } & \multicolumn{5}{c}{ Production cost (Tk/ kg) } \\
\cline { 2 - 6 } & Fish Species & Before IAPP & After IAPP & Increase $(\%)$ & t-value \\
\hline \multirow{2}{*}{ Rangpur } & Tilapia & 56 & 66 & 17 & 15.44 \\
& Thai Koi & 70 & 81 & 15 & 14.99 \\
\multirow{2}{*}{ Barisal } & Tilapia & 68 & 84 & 23 & 28.04 \\
& Pangus & 73 & 84 & 15 & 15.81 \\
\hline
\end{tabular}

On the other hand, Tilapia production cost was higher in Barisal compared to Rangpur. Before IAAP, per kg Tilapia production cost was only Tk.68, which grew upto Tk. 84 after IAAP, implies that about $23 \%$ production cost has increased after IAAP implementation for Tilapia in Barisal region. On the contrary, cost of Pangus production has increased by 15\% in Barisal after IAPP technology, which is same as Rangpur.
Table 10 represents per acre profit on the basis of species in Rangpur and Barisal region. Result reveals that per acre profit was only Tk.86671 for Tilapia farming before IAPP whereas it increased to Tk. 234853 after IAPP i.e. profit increased 2.7 times or $170 \%$ after IAPP in Rangpur region. At the same time, profit from Thai Koi has increased about 189\% after IAPP (from Tk. 78273 to Tk. 226976). These increased rates were statistically significant at $1 \%$ level. 
Table 10. Average profit (Tk. acre) of Rangpur and Barisal region.

\begin{tabular}{cccccc}
\hline \multirow{2}{*}{ Particulars } & \multicolumn{5}{c}{ Net Profit (Tk/ acre) } \\
\cline { 2 - 6 } & Fish Species & Before IAPP & After IAPP & Increase (\%) & t-value \\
\hline \multirow{2}{*}{ Rangpur } & Tilapia & 86671 & 234853 & 170 & 16.54 \\
& Thai Koi & 78273 & 226976 & 189 & 24.15 \\
\multirow{2}{*}{ Barisal } & Tilapia & 71550 & 118300 & 65 & 14.39 \\
& Pangus & 116000 & 215833 & 86 & 16.84 \\
\hline
\end{tabular}

On the other hand, the percentage of increase of profit is comparatively lower in Barisal than Rangpur region. In case of Tilapia, per acre profit increased about 1.65 times which was statistically significant at $1 \%$ level. Similarly, profit increased about $86 \%$ after using of IAPP technology in case of Pangus farming and this positive impact was statistically significant at $1 \%$ level. Therefore, it may conclude that, farmers can significantly increase Tilapia, Thai Koi and Pangus production as well as can maximize profit using IAPP technology.

\section{Discussion}

Before involvement with IAPP, most of the farmers stocked fry from local fry traders. But after involvement with IAPP, farmers stocked fry in their ponds from selected IAPP assisted hatchery to ensure good quality fish fry for increased fish production. After engaged with IAPP, most of the farmers of followed BFRI evolved technologies to get more fish production. Prior to IAPP, the farmers' average fish production of Tilapia, Koi and Pangus were 2,451, 2,002 and $7,810 \mathrm{~kg}^{2}$ acre $^{-1}$, respectively. After involvement of IAPP intervention, the farmers' fish productions were 3,$997 ; 3,655$ and 11,176 kg acre $^{-1}$, respectively. Islam and Haque (2010) stated that the average yield was $1,144 \mathrm{~kg} \mathrm{acre}^{-1}$ in Northwest Fisheries Extension Project, which was remarkable less than the present study. According to FRSS (2016), the national average pond fish production in Bangladesh was 1,558 kg acre $^{1}$. From the above, fish production was being increased because of the involvement with IAPP and farmers used genetically improved fry and BFRI evolved culture technology for their culture management.

Fish farming has a positive impact on aquaculture production but numerous types of constraints affect potentiality of fish farming in the Rangpur and Barisal region. Very poor retention capacity of soil, sudden tidal flow, flash flood, sudden cyclone, lack of loan facilities, low quality and scarcity of fish seeds in proper time etc. Rahman
(2003) stated that the major constraints of carp farming were lack of money and production cost. Khan et al. (1998) identified that the lack of knowledge about fish culture was one of the most important problems. Hossain et al. (1992) observed that the largest problems faced by the fish farmers are multiple ownerships.

\section{Acknowledgement}

The authors are grateful to the World Bank for providing funds through Integrated Agricultural Project (IAPP), Bangladesh to carry out this study.

\section{References}

FRSS. 2016. Fisheries Statistical Report of Bangladesh. Fisheries Resources Survey System (FRSS), Department of Fisheries, Bangladesh. 31: 57.

Hossain, M.S., Dewan, S., Islam M.S. and Hossain, S.M.A. 1992. Survey of pond fishery resources in a village of Mymensingh district. Bangladesh J . Aqua. 14-16: 33-37.

Islam, M.R. and Haque M.R. 2010. Impacts of Northwest Fisheries Extension Project (NFEP) on pond fish farming in improving livelihood approach. J. Bangladesh Agril. Univ. 8(2): 305-311.

Khan, A.N.M.I., Rahman, M.M. and Islam M.A. 1998. Factor causing difficulty in pond fish culture in a selected area of Mymensingh district. Bangladesh J. Aqua. 20: 23-27.

Mazid, M.A. and Sinha, V.R.P. 2000. Bangladeshe Grameen Matsyachash Parikalpona Abang Unnayan in BFRI, Proceedings of the National Seminar on Rural and Coastal Aquaculture in Poverty Alleviation, BFRI, Mymensingh, Bangladesh, Fish Week. pp. 23-33.

Rahman, M.M. 2003. Socio-economic aspects of carp culture development in Gazipur, Bangladesh. M.S. Dissertation, Department of Agricultural Economics, Bangladesh Agricultural University, Mymensingh. 83p. 